\title{
Influence of supplementation with inactivated dry yeasts during the tirage of sparkling wines (Cava) on its composition, its foaming properties and its sensorial quality
}

\author{
Laura Medina-Trujillo $^{1}$, Elena González-Royo ${ }^{1}$, Nathalie Sieczkowski ${ }^{2}$, José M. Heras ${ }^{2}$, Francesca Fort ${ }^{1}$, \\ Joan Miquel Canal ${ }^{1}$, and Fernando Zamora ${ }^{1}$ \\ ${ }^{1}$ Departamento de Bioquímica y Biotecnología, Facultad de Enología de Tarragona, Universidad Rovira i Virgili, C/ Marcel.lí \\ Domingo, 1, 43007 Tarragona, España \\ ${ }^{2}$ Lallemand Bio S.L. C/ Galileu 303, 1ª planta. 08028 Barcelona, España
}

\begin{abstract}
Different sparkling wines were elaborated with a base wine of Macabeo from the AOC Cava using the traditional method with supplementation or not of inactivated dry yeasts of Saccharomyces cerevisiae (Optimumwhite ${ }^{\mathrm{TM}}$ ) or Torulaspora delburueckii (TD291). After 9 months, the samples were analyzed and tasted. The supplementation with both IDY (S. cerevisiae and T. delbrueckii) produced Cavas with better foaming properties than the Cava control. The tasters could significantly distinguish between the Cavas supplemented with both IDY from the Cava control. Moreover, taster clearly preferred the Cava elaborated with supplementation of IDY of T. delburueckii than the control one.
\end{abstract}

\section{Introduction}

There are different effervescent beverages including carbonated drinks, beer and, of course, sparkling wines. Their effervescence and their foam are very different. Thus, gasified beverages generally have a very tumultuous effervescence, with large bubbles and relatively short foam persistence. On the opposite side we find beer, with a weak effervescence, very fine bubbles and extremely persistent foam. Well, sparkling wines have intermediate properties, which is very important to guarantee their organoleptic characteristics [1].

It should be taken into account that effervescence and foam are not only visual attributes linked to the beauty of sparkling wines but have also significantly influence the sensations perceived on the palate [2]. A carbonated beverage with a tumultuous effervescence and large bubbles leads to a feeling of aggressiveness in the mouth. In the same way, it will quickly lose its effervescence, given the rapid evolution of gas observed in this type of product. On the contrary, a quality sparkling wine, will present in the mouth a pleasant tingling accompanied by the sensation of creaminess that generates its foam. For these reasons, the effervescence must last the time necessary for the consumer to enjoy their tasting.

For all that reasons, the sparkling winemakers are especially interested in understanding what the sparkling properties depend on and how they can improve them $[3,4]$. The sparkling wines made by the traditional method develop the second fermentation in the bottle and are maintained in aging with the lees to enrich the wine in proteins, mannoproteins and polysaccharides with the aim of obtaining better effervescence and foam [5,6]. Long contact with the lees gives a greater aromatic and gustatory complexity and a better integration of the carbonic gas $[7,8]$.
The yeasts' autolysis is the main responsible for these changes [9]. However, long aging is costly and for this reason there is interest in techniques that allow obtaining better foam in shorter time. Supplementation with inactivated dry yeasts (IDY) as additional source of proteins, mannoproteins and polysaccharides has been proposed for this purpose $[2,10]$. However, there are no scientific studies that support its usefulness. For this reason, the aim of this study was to determine if the supplementation with specific IDYs during the tirage really improves the foaming properties of sparkling wines.

\section{Materials and methods}

The elaboration of the sparkling wines (Cava) was made by the traditional method with a Macabeo base wine. 36 bottles were prepared. Twelve of them were added with $30 \mathrm{mg} / \mathrm{L}$ of a specific glutathione-rich IDY from a Saccharomyces cerevisiae yeast (Optimumwhite ${ }^{\mathrm{TM}}$, Lallemand Inc.). Another 12 bottles were added with $30 \mathrm{mg} / \mathrm{L}$ of an experimental IDY of Torulaspora delbrueckii TD291 (Lallemand Inc.). The remaining 12 bottles were considered as control. The sparkling wines were disgorged, analyzed and tasted 9 months later.

The analytical methods recommended by the OIV were used to determine the ethanol content, titratable acidity, $\mathrm{pH}$ and volatile acidity [11]. Glycerol and sugars (D-glucose and D-fructose) were measured using enzymatic kits (R-Biopharm AG., Darmstadt, Germany). The foaming properties were determined by Mosalux method [12]. Proteins were analyzed by HRSEC-DAD [13]. The polysaccharides were determined by HRSECRID [14]. The sensorial analysis was performed with 12 trained oenologists by triangular test. 

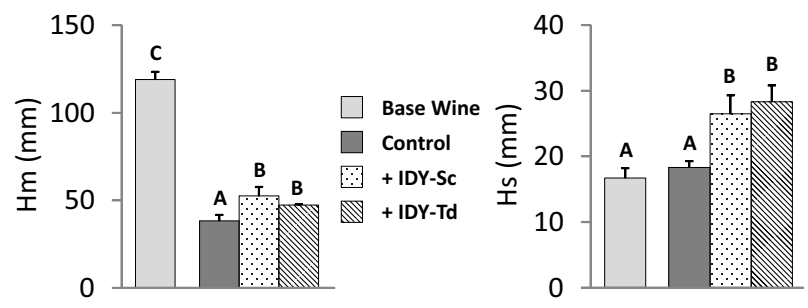

Figure 1. Hm: maximum height of the foam; Hs: stable height of the foam. + IDY-Sc: supplemented with inactive dry yeasts of S. cerevisiae; + IDY-Td: supplemented with inactive dry yeast from T. delbrueckii. Different letters indicate the existence of statistically significant differences $(\mathrm{p}<0.05)$.

All data are expressed as the arithmetic average \pm the standard deviation from three replicates. One-factor analysis of variance (ANOVA) and Tukey's test were carried out with SPSS software (SPSS Inc., Chicago, Illinois, USA).

\section{Results and discussion}

Table 1 shows the influence of supplementation with inactive dry yeasts during the second fermentation in the general parameters of sparkling wines.

All the sparkling wines have higher alcoholic strength, $\mathrm{pH}$, volatile acidity and glycerol concentration, and lower titratable acidity than the original base wine. These differences were expected and attributable to the natural changes produced by the second fermentation. No differences on ethanol, titratable acidity, $\mathrm{pH}$ and volatile acidity were found between the different sparkling wines. However, glycerol levels were significant higher in the Cavas supplemented with both IDY.

Figure 1 shows the foam parameters of the original base wine and the different sparkling wines.

As expected, the maximum foam height $(\mathrm{Hm})$ of all Cavas was significantly lower than that of their base wine. This drastic reduction of $\mathrm{Hm}$, already described in previous studies $[15,16]$, has been attributed to the increase of the ethanol produced during the second fermentation and the absorption of proteins by the bentonite used with adjuvant [17].

The supplementation with both IDY (S. cerevisiae and $T$. delbrueckii) produced Cavas with better foaming properties than the Cava control. Thus, both parameters, $\mathrm{Hm}$ and $\mathrm{Hs}$, were significantly higher in sparkling wines supplemented with both IDY than in their corresponding control. It should be noted that the increase of both Hm and Hs was similar in the Cavas supplemented with IDY of $S$. cerevisiae and those supplemented with IDY of $T$. delbrueckii.

In contrast, no significant differences were found in protein and polysaccharide composition between Cavas supplemented with IDY and the Cava control (Data not shown). In this sense, it should be noted that some previous studies have shown that supplementation with IDY of the sparkling wines led to an increase of the concentration in proteins [2] while in others this effect was not detected [18]. In our case, no differences were observed between the Cava control and the other two supplemented with the two LSI, probably because the protein decrease generated in the Cavas was higher than the sensitivity limit of the analytical method.
Table 1.

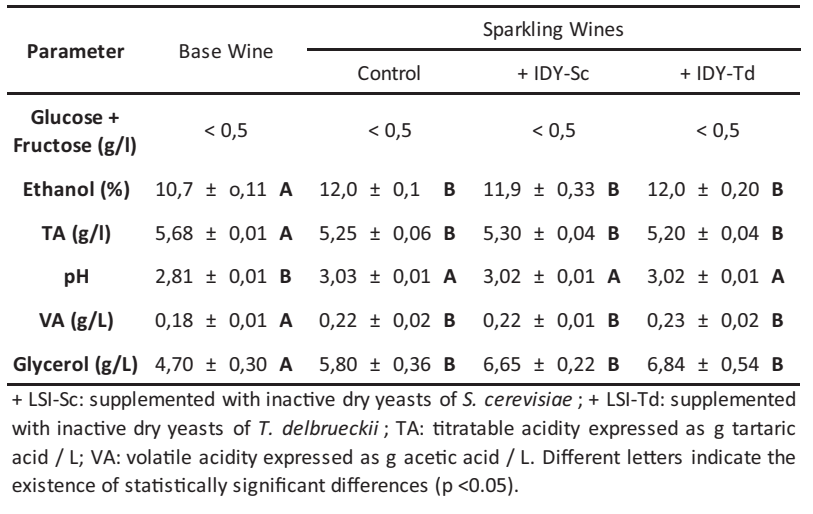

Table 2.

\begin{tabular}{lccccc}
\hline \multirow{2}{*}{$\begin{array}{c}\text { Triangular } \\
\text { Test }\end{array}$} & $\begin{array}{c}\text { Positive } \\
\text { Identifications }\end{array}$ & $p$ & \multicolumn{3}{c}{ Preferences } \\
\cline { 4 - 6 } & & & Control $+I D Y-S C$ & $+I D Y-T d$ \\
\hline Control vs + IDY-Sc & $9 / 12$ & 0.01 & 5 & 4 & - \\
Control vs + IDY-Td & $11 / 12$ & $<0,001$ & 3 & - & 8 \\
\hline
\end{tabular}

+ IDY-Sc: supplemented with inactive dry yeasts of S. cerevisiae; + IDY-Td: supplemented with inactive dry yeast from $T$. delbrueckii.

Table 2 shows the results of the comparative sensorial analysis (triangular test) between sparkling wines supplemented with inactive dry yeasts and control.

Nine of the 12 tasters could distinguish between the Cava supplemented with IDY of S. cerevisiae and the Cava control. This result is significant $(p<0.01)$ and demonstrates that both sparkling wines were different from the sensory point of view.

Among the tasters who were able to differentiate which was the different sample, 5 of them preferred the Cava control and 4 the Cava supplemented with IDY of $S$. cerevisiae, thus it exists a technical tie in their preferences since the tasters did not selected one of the samples clearly

The results were much clearer when comparing Cava control with that supplemented with IDY of $T$. delbrueckii. Specifically 11 of the 12 tasters were able to distinguish between both Cavas, which allows to affirm that the samples were different in a very significant way ( $p<0.001)$. In addition 8 of the 11 tasters who were able to distinguish between samples preferred the Cava supplemented with IDY of T. delbrueckii which clearly indicates that this Cava was better appreciated from the sensory point of view.

It can be concluded therefore that the supplementation with specific IDY is an interesting tool to improve the foam and the general quality of the sparkling wines.

This study has been funded by CDTI (CIEN-VINySOST2014 project).

\section{References}

[1] F. Zamora, Enólogos 23, 28-32 (2003)

[2] G. Vanrell, P. Cabanillas, S. Albet, JM. Canals, L. Arola, F. Zamora, F. 2002. Rev. Fr. OEnol. 196, 30-36 (2002) 
[3] A. Maujean, Rev. Fran. Enol., 120, 11-17 (1989)

[4] G. Vanrell, M., Esteruelas, JM. Canals, F. Zamora, P. Poinsaut, N. Sieczkowski, D. Leboeuf, Rev. Oenol. 114, 28-30 (2005)

[5] BEN. Todd, GH. Fleet, PA. Henschke, P. A. Am. J. Enol. Vitic. 51, 65-72 (2000)

[6] Y.P. Núñez, AV. Carrascosa, R. González, MC. Polo, A. Martínez-Rodríguez, J. Agric. Food Chem. 54, 7898-7903 (2006)

[7] F. Brissonet, A. Maujean, Am. J. Enol. Vitic. 44, 297-301 (1993)

[8] C. Luguera, V. Moreno-Arribas, E. Pueyo, B. Bartolomé, MC. Polo, Food Chemistry 63, 465-471 (1998)

[9] MJ. Leroy, M. Charpentier, B. Duteurtre, M. Feuillat, C. Charpentier, Am. J. Enol. Vitic. 41, 21-28 (1990)

[10] L. Martínez-Lapuente, Z. Guadalupe, B. Ayestarán, M. Ortega-Heras, S. Pérez-Magariño, J. Agric. Food Chem. 61, 12362-12373 (2013)
[11] Organisation Internationale de la Vigne et du Vin. Methods of analysis of wines and must (2014)

[12] A. Maujean, P. Poinsaut, H. Dantan, F. Brissonet, E. Cossiez, Bulletin de l'OIV 711-712, 405-426 (1990)

[13] J.M. Canals, L. Arola, F. Zamora, Am. J. Enol. Vitic. 49, 383-388 (1998)

[14] B. Ayestarán, Z. Guadalupe, D. León, 2004. Anal Chim Acta 513, 29-39 (2004)

[15] E. Pueyo, PJ. Martín-Alvarez, MC. Polo, Am. J. Enol. Vitic. 46, 518-524 (1995)

[16] M. Esteruelas, E. González-Royo, N. Kontoudakis, A. Orte, A. Cantos, JM. Canals, F. Zamora, F. J. Sci. Food Agric. 95, 2071-2080 (2015)

[17] G. Vanrell, R. Canals, M. Esteruelas, F. Fort, JM. Canals, F. Zamora, Food Chem. 104, 148-155 (2007)

[18] S. Pérez-Magariño, L. Martínez-Lapuente, M. Bueno-Herrera, B. Ayestarán, J. Agric. Food Chem. 63, 5670-5681 (2015) 